\title{
COMMUNICATION IN PRACTICE
}

TONY ASTLE

BARRY JACKSON

CHRIS WEBB 
(C) Tony Astle 1976
(C) Barry Jackson 1976
Chris Webb 1976

All rights reserved. No part of this publication may be reproduced or transmitted, in any form or by any means, without permission.

First published 1976 by

THE MACMILLAN PRESS LTD

London and Basingstoke

Associated companies in New York Dublin

Melbourne Johannesburg and Madras

SBN 333188349

ISBN 978-0-333-18834-7

DOI 10.1007/978-1-349-02736-1

ISBN 978-1-349-02736-1 (eBook)

This book is sold subject to the standard conditions of the Net Book Agreement.

The paperback edition of this book is sold subject to the condition that it shall not, by way of trade or otherwise, be lent, re-sold, hired out, or otherwise circulated without the publisher's prior consent in any form of binding or cover other than that in which it is published and without a similar condition including this condition being imposed on the subsequent purchaser. 


\section{EDITOR'S NOTE}

This workbook in Communication is intended for young people in the last year at school and first-year students in Further Education, whether they be operative, craft or technician apprentices or following some other course. The book aims to combine the basic elements of Communication with ample provision of work for the students to reinforce their learning. The points are underlined by pertinent illustrations.

We hope you will enjoy using it.

Henley College of Further Education, HARRY SPENCE Coventry General Editor

\section{ACKNOWLEDGEMENTS}

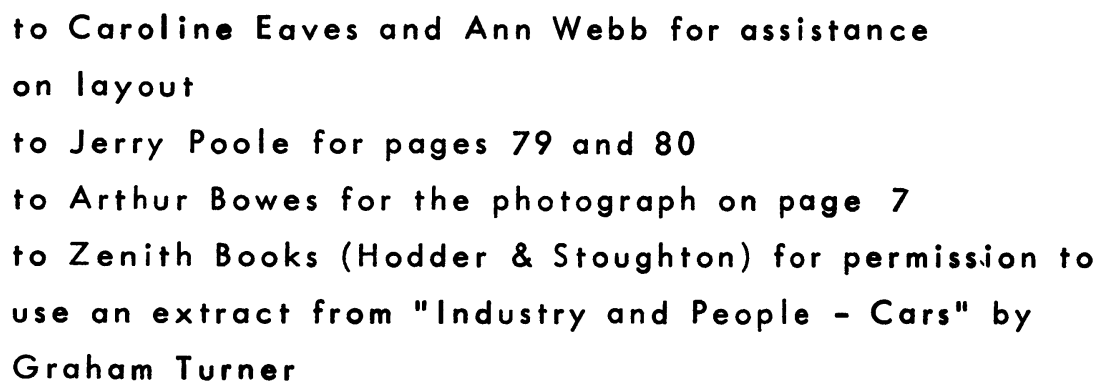




\section{CONTENTS}

SPEAKING AND LISTENING

1. First impressions

2. Paying attention

3. Better speech

WRITING AND READING

4. Why write at all?

5. What do I want to say?

6. What reader am I writing for?

7. How much do I have to write?

8. What does my reader know already?

SHOWING AND LOOKING

9. Pictures or words?

10. Pictures as words

11 Pictures and words

NOW ......CONNECT!

IN THIS BOOK D MEANS SOMETHING TO DO

- MEANS SOMETHING TO REMEMBER 